\title{
Prediksi Proses Persalinan Menggunakan Case Based Reasoning
}

\author{
Tursina $^{\# 1}$

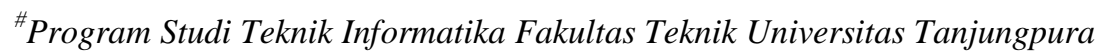 \\ tursina@informatics.untan.ac.id
}

\begin{abstract}
Abstrak-.Penelitian ini mengusulkan salah satu pendekatan dalam memprediksi proses persalinan menggunakan Case Based Reasoningr. Case Based Reasoning (CBR) merupakan suatu penalaran yang mengambil kesimpulan atau solusi dengan cara mengadopsi solusi yang sudah ada (kasus terdahulu). Hal yang terpenting dalam CBR adalah menentukan nilai kemiripan atau similaritas antara kasus-kasus yang tersimpan di basis kasus dengan kasus baru yang akan dicari solusinya. Salah satu metode similaritas yang bisa digunakan adalah dengan cara Algoritma Nearest Neighbor. Sistem CBR mempunyai 4 tahapan yaitu Retrieve, Reuse, Revise dan Retain. Aplikasi CBR ini menggunakan framework dan GUI jCOLIBRI
\end{abstract}

Kata kunci - Prediksi, CBR, Algoritma Nearest Neighbor, jCOLIBRI

\section{Pendahuluan}

Lebih dari 90\% kematian ibu disebabkan komplikasi obstetric, yang sering tak diramalkan saat kehamilan. Kebanyakan komplikasi itu terjadi pada saat atau sekitar persalinan Banyak di antara ibu yang tidak dikategorikan berisiko, ternyata mengalami komplikasi dan sebaliknya sehingga pada saat persalinan harus dilakukan dengan operasi Caesar. Diperkirakan $15 \%$ kehamilan akan mengalami keadaan risiko tinggi dan komplikasi obstetric, yang dapat membahayakan kehidupan ibu maupun janinnya bila tidak ditangani dengan memadai [1].

Ibu hamil yang termasuk golongan kehamilan dengan resiko tinggi adalah ibu dengan ciri-ciri diantaranya adalah sebagai berikut:[2]

- Riwayat kehamilan dan persalinan yang sebelumnya kurang baik Contohnya: riwayat keguguran, perdarahan pasca kelahiran, dan lahir mati

- Usia ibu hamil kurang dari 20 tahun atau lebih dari 35 tahun

- Jarak antara dua kehamilan kurang dari 2 tahun.

- Ibu menderita anemia atau kurang darah.

- Tekanan darah yang meninggi dan sakit kepala hebat dan adanya bengkak pada tungkai

- Kelainan letak janin atau bentuk panggul ibu tidak normal

- Riwayat penyakit kronik.

- Riwayat obstetric jelek.

Masih banyak lagi ciri - ciri atau gejala yang menyebabkan Ibu hamil beresiko tinggi. Ibu hamil dengan kehamilan resiko tinggi memiliki kemungkinan yang lebih besar menjalani persalian melalui operasi Caesar atau Induksi. Apabila kemungkinan ini dapat diprediksi dari awal maka ibu hamil dapat mempersiapkan diri dengan lebih memperhatikan perawatan kesehatannya.

Dalam penelitian ini, Case Based Reasoning (CBR) digunakan untuk memprediksi proses persalinan ibu hamil apakah melalui Operasi Caesar atau persalinan normal berdasarkan kasus-kasus yang pernah terjadi. Pemanfaatan CBR dalam bidang kesehatan bukanlah hal baru. Awal mula pemanfaatan CBR dalam bidang kesehatan adalah digunakan untuk menentukan terapi bagi penderita suatu penyakit. Penelitian CBR untuk memprediksi proses persalinan ibu hamil diharapkan bermanfaat memberikan informasi sejak dini tentang kemungkian resiko melahirkan secara Caesar sehingga ibu hamil dapat mempersiapkan diri dengan lebih memperhatikan perawatan kesehatannya

\section{LANDASAN TEORI}

\section{A. Case Based Reasoning}

Case Based Reasoning (CBR) adalah salah satu metode pndekatan berbasis pengetahuan untuk mempelajari dan memecahkan masalah berdasarkan pengalaman pada masa lalu [3]. Pengalaman yang lalu dikumpulkan dan disimpan dalam tempat yang disebut Basis Kasus. Basis kasus adalah kumpulan kasus-kasus yang pernah terjadi. Sebuah kasus baru diselesaikan dengan mencari kasus-kasus yang telah tersimpan dalam basis kasus yang memiliki kemiripan dengan kasus baru tersebut.

Apabila tidak ditemukan kasus yang memiliki kemiripan maka solusi dari kasus tersebut adalah analisa dari pakar atau ahli tentang kasus tersebut, dan kemudian akan dijadikan suatu kasus baru yang disimpan dalam basis kasus.

\section{B. Metodologi CBR}

Untuk menghasilkan solusi suatu masalah, CBR harus melakukan beberapa tahapan proses. Tahapan proses yang terjadi dalam CBR dapat dilihat pada Gambar 1.

Tahapan proses pada CBR dalam mencari nilai kemiripan dibutuhkan empat (4) tahap, yaitu :

1. Retrieve (penelusuran) adalah menemukan kembali kasus yang sama atau yang paling mirip dengan kasus baru

2. Reuse adalah menggunakan kembali informasi dan pengetahuan dari basis kasus untuk memecahkan masalah kasus baru.

3. Revise adalah merevisi atau memperbaiki solusi yang diusulkan. 
4. Retain adalah menyimpan pengalaman untuk memecahkan masalah yang akan datang kedalam basiskasus. Nilai kemiripan (similarity) yang digunakan adalah range antara 0 sampai 1.

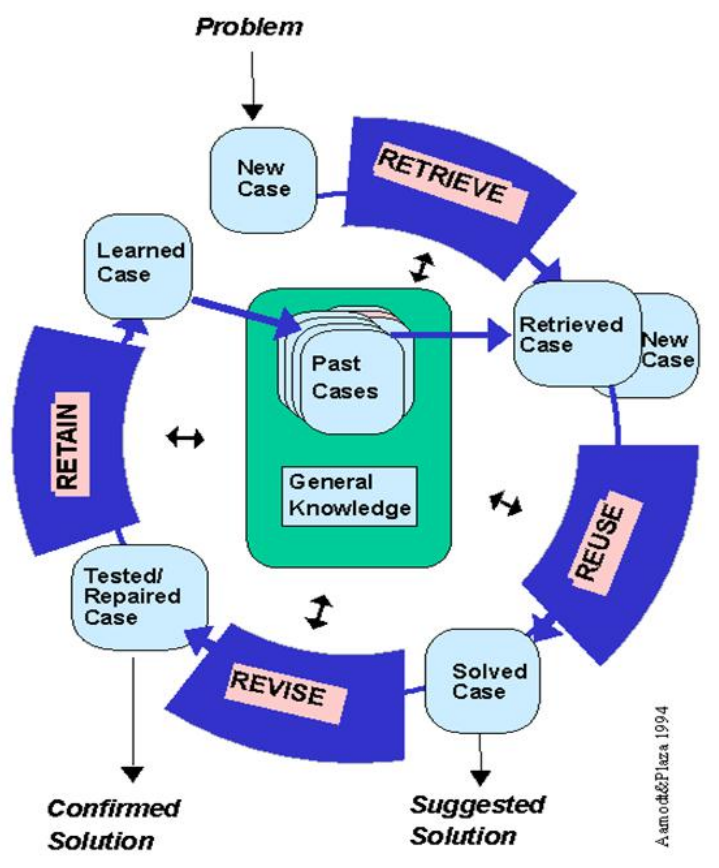

Gambar. 1 Tahapan Sistem CBR [4]

\section{Kehandalan $C B R$}

Kehandalan CBR antara lain [5] :

1. Pengetahuan didapatkan dengan cara mengumpulkan kejadian atau pengalaman yang telah terjadi.

2. Kerja semakin berkurang karena mengutamakan membuat suatu identifikasi yang signifikan terhadap suatu masaalah, ini lebih mudah dari pada harus membuat suatu model yang explicit.

3. Penggunaan teknik database, informasi yang besar dapat diatur.

4. CBR sistim dapat belajar dengan mempelajari pengetahuan yang baru sebagai kasus. Hal ini membuat perbaikan lebih mudah

Kendala yang harus diperhatikan:

- Suatu kasus tidak mencakup keseluruhan dari bidang yang ingin diketahui

- Kasus yang benar-benar sesuai akan sulit untuk didapatkan

- Tetap memerlukan kesamaan, adaptasi dan verifikasi pengetahuan

\section{Algoritma Nearest Neighbor}

Nearest Neighbor adalah pendekatan untuk mencari kasus dengan menghitung kedekatan antara kasus baru dengan kasus lama, yaitu berdasarkan pada pencocokan bobot dari sejumlah fitur yang ada [6]. Misalkan diinginkan untuk mencari solusi terhadap seorang pasien baru dengan menggunakan solusi dari pasien terdahulu. Untuk mencari kasus pasien mana yang akan digunakan maka dihitung kedekatan kasus pasien baru dengan semua kasus pasien lama. Kasus pasien lama dengan kedekatan terbesar-lah yang akan diambil solusinya untuk digunakan pada kasus pasien baru. Ilustrasi kedekatan kasus direpresentasikan dengan Gambar 2.

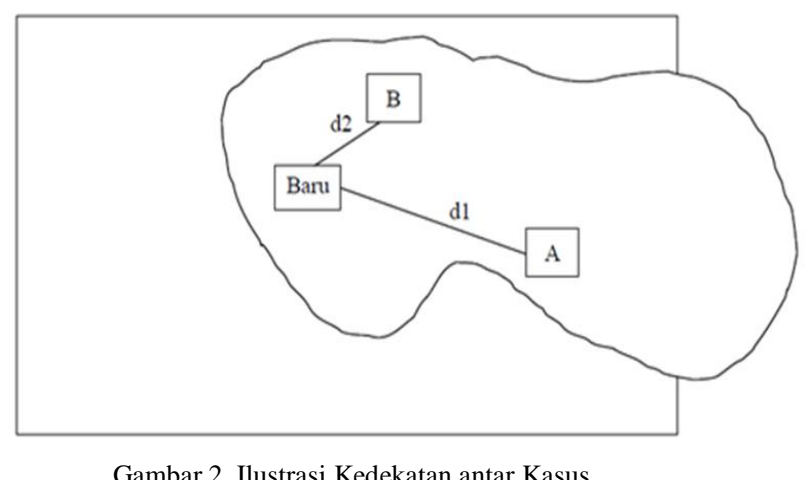

Seperti tampak pada Gambar 2, misalnya pada domain kesehatan yaitu mencari solusi treatment terbaik untuk suatu penyakit berdasarkan kasus-kasus yang ternah terjadi. Jika terdapat dua pasien lama A dan B. Ketika ada pasien baru, maka solusi yang akan diambil adalah solusi dari pasien terdekat dari pasien baru. Seandainya d1 adalah kedekatan antara pasien baru dan pasien $\mathrm{A}$, sedangkan $\mathrm{d} 2$ adalah kedekatan antara pasien baru dengan pasien B. Oleh karena d2 lebih dekat dari d1maka solusi dari pasien B yang akan digunakan untuk memberikan solusi pasien Baru.

Adapun rumus untuk melakukan penghitungan kedekatan(similarity) antara dua kasus dapat dilihat pada persamaan 1 .

$\operatorname{Similarity}(T, S)=\frac{\sum_{i=1} f\left(T_{i}, S_{i}\right) x W_{i}}{W_{i}}$

dengan:

$\mathrm{T}$ : kasus baru

$\mathrm{S}$ : kasus yang ada dalam penyimpanan

$\mathrm{n}$ : jumlah atribut dalam masing-masing kasus

$\mathrm{i}$ : atribut individu antara $1 \mathrm{~s} / \mathrm{d} \mathrm{n}$

f : fungsi similarity atribut $\mathrm{i}$ antara kasus $\mathrm{T}$ dan kasus $\mathrm{S}$

$\mathrm{W}$ : bobot yang diberikan pada atribut $\mathrm{i}$

\section{E. jCOLIBRI}

jCOLIBRI adalah sebuah kerangka kerja berorientasi objek berbasis Java yang digunakan untuk membangun sistem Case Based Reasoning (CBR). Framework adalah aplikasi semicomplate yang dapat digunakan kembali (reuse) untuk memproduksi aplikasi tertentu.

Instansiasi framework didukung dengan GUI yang memadai untuk mengkonfigurasikan bagian-bagian dari sistem CBR. jCOLIBRI dibangun mencakup sebuah task/ontology, sebuah deskripsi level pengetahuan yang memandu perancangan framework, menentukan perluasan yang mungkin mendukung proses instansiasi framework [7] 
Ontology domain dari kasus yang diselesaikan bersifat independent dan dipetakan $\mathrm{k}$ edalam kelas-lekas yang ada dalam framework.

\section{PERANCANGAN}

Untuk membangun Aplikasi CBR tahapan pertama yang dilakukan adalah menentukan atribut kasus kemudian membuat basis kasus dan menentukan metode similaritas yang dilakukan pada saat proses Retrive.

\section{A. Menentukan atribut}

Menentukan fitur atau atribut pada sistem CBR sangat penting karena atribut tersebut yang nantinya akan membentuk suatu kasus. Beberapa atribut yang dapat digunakan untuk memprediksi proses persalinan antara lain.:

1. Usia

2. Jarak Persalinan

3. Lebar panggul

4. Riwayat Caesar

5. Riwayat penyakit

6. Proses Persalinan/Kelahiran

Kesemua atribut tersebut memiliki peran yang sama pentingnya dalam melakukan prediksi proses persalinan. Untuk menyederhanakan nilai untuk masing-masing atribut maka nilai tersebut dibagi kedalam katagori-katagori seperti tertera pada Tabel 1.

TABEL 1

KATEGORI NILAI PADA ATRIBUT

\begin{tabular}{|l|ll|}
\hline Atribut & \multicolumn{2}{|l|}{ Katagori } \\
\hline Usia & $\begin{array}{l}\text { 1. } \quad<=25 \mathrm{thn} \\
\end{array}$ & $2 . \quad 26 \mathrm{~s} / \mathrm{d} 35 \mathrm{thn}$ \\
& $3 . \quad>35 \mathrm{thn}$ \\
\hline Jarak persalinan & $1 . \quad<2 \mathrm{thn}$ \\
& $2 . \quad>=2 \mathrm{thn}$ \\
\hline Lebar Panggul & $1 . \quad$ Besar \\
& $2 . \quad$ Kecil \\
\hline Riwayat Caesar & $1 . \quad$ Ya \\
& $2 . \quad$ Tidak \\
\hline Riwayat penyakit & $1 . \quad$ Ada \\
& $2 . \quad$ Tidak ada \\
\hline Proses Melahirkan & $1 . \quad$ Normal \\
& $2 . \quad$ SC \\
\hline
\end{tabular}

\section{B. Membangun Basis Kasus}

Tahapan kedua adalah membangun Basis Kasus yang digunakan unutk meninpan kasus-kasus yang terdahulu. . Pada penelitian ini digunakan MySQL sebab MySQL merupakan DBMS yang handal untuk meng-handle data dalam jumlah yang besar serta termasuk dalam katagori freeware.

Dalam basis kasus hanya terdapat 1 tabel yang terdiri dari 7 field. Untuk deskripsi detail dari struktur tabel dapat dilihat pada Gambar 3

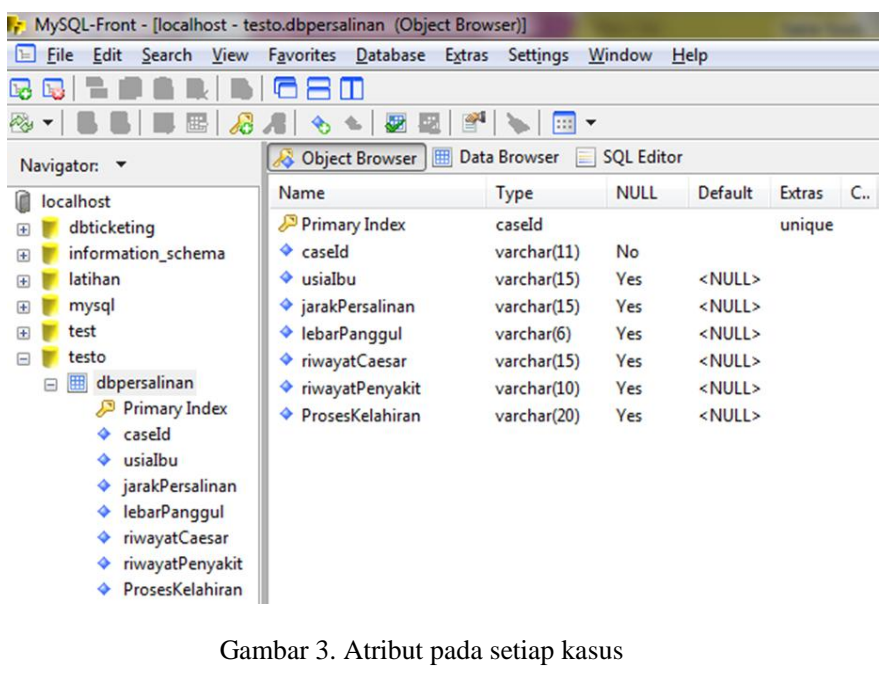

\section{Retrieve Phase}

Dalam mencari kasus yang memiliki kemiripan(similarity) dengan kasus baru digunakan algoritma Nearest Neighbor. Hal ini dikarenakan jCOLIBRI mendukung algoritma ini untuk retrieve phase. Terdapat 2 method yang disediakan JCOLIBRI untuk memilih kasus yang terbaik, yaitu:

1. Select Best Case Method untuk menentukan satu saja kasus yang terbaik.

2. Select Some Case Method untuk memilih sejumlah N kasus yang terbaik berdasarkan ranking similarity yang terdekat dengan kasus baru yang sedang dihadapi. N merupakan paramater input yang bisa didefiniskan secara bebas.

Untuk kasus ini, yang digunakan adalah method yang pertama yaitu memilih satu saja kasus yang terbaik. Algoritma Nearest Neigbor sebelum menghitung similarity, tiap atribut harus diberikan bobot dan kedekatan nilai-nilai dalam atribut juga perlu didefinisikan. Hal ini dapat dilihat pada Gambar 4.

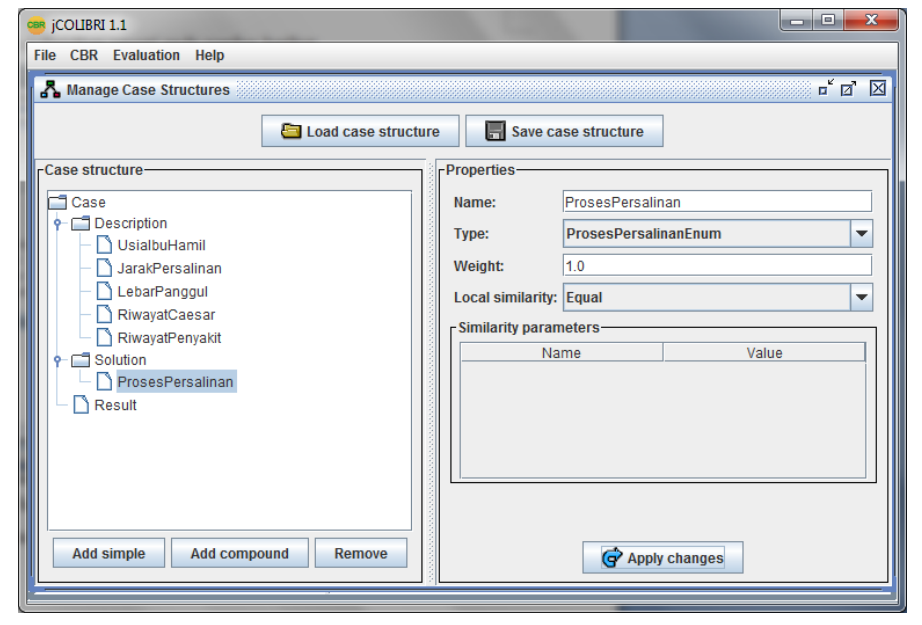

Gambar 4. Menu Entry Struktur Kasus 
Pembobotan tiap atribut dapat dilihat pada Tabel 2. Tiap atribut bernilai sama hal ini disebabkan karena semua atribut merupakan faktor yang sama penting dalam mempengaruhi apakah ibu hamil akan melahirkan normal atau melalui operasi.

TABEL 2

KATEGORI NILAI PADA ATRIBUT

\begin{tabular}{|c|c|}
\hline Atribut & Bobot \\
\hline Usia & 1 \\
\hline Jarak Persalinan & 1 \\
\hline Lebar Panggul & 1 \\
\hline Riwayat Caesar & 1 \\
\hline Riwayat Penyakit & 1 \\
\hline
\end{tabular}

.Kedekatan antara nilai-nilai atribut juga perlu didefinisikan. Kedekatan nilai atribut usia ditunjukkan pada Tabel 3, kedekatan nilai atribut jarak persalinan pada Tabel 4, kedekatan nilai atribut lebar panggul pada Tabel 5, kedekatan nilai atribut riwayat Caesar pada Tabel 6 dan kedekatan nilai atribut riwayat penyakit pada Tabel 7 .

TABEL 3.

KEDEKATAN NILAI ATRIBUT USIA (U)

\begin{tabular}{|c|c|c|}
\hline Nilai 1 & Nilai 2 & Similarity \\
\hline$<=25$ tahun & $<=25$ & 1 \\
\hline$<=25$ & $26 \mathrm{~s} / \mathrm{d} 35$ & 0.75 \\
\hline$<=25$ & $>35$ & 0.5 \\
\hline $26 \mathrm{~s} / \mathrm{d} 35$ & $<=25$ & 0.75 \\
\hline $26 \mathrm{~s} / \mathrm{d} 35$ & $26 \mathrm{~s} / \mathrm{d} 35$ & 1 \\
\hline $26 \mathrm{~s} / \mathrm{d} 35$ & $>35$ & 0.5 \\
\hline$>35$ & $<=25$ & 0.5 \\
\hline$>35$ & $26 \mathrm{~s} / \mathrm{d} 35$ & 0.5 \\
\hline$>35$ & $>35$ & 1 \\
\hline
\end{tabular}

TABEL 4.

KEDEKATAN NILAI ATRIBUT JARAK PERSALINAN (JP)

\begin{tabular}{|c|c|c|}
\hline Nilai 1 & Nilai 2 & Similarity \\
\hline$<2$ tahun & $<2$ tahun & 1 \\
\hline$>=2$ tahun & $<2$ tahun & 0.5 \\
\hline$<2$ tahun & $>=2$ tahun & 0.5 \\
\hline$>=2$ tahun & $>=2$ tahun & 1 \\
\hline
\end{tabular}

TABEL 5.

KEDEKATAN NILAI ATRIBUT LEBAR PINGGUL (LP)

\begin{tabular}{|c|c|c|}
\hline Nilai 1 & Nilai 2 & Similarity \\
\hline Besar & Besar & 1 \\
\hline Besar & Kecil & 0.5 \\
\hline Kecil & Besar & 0.5 \\
\hline Kecil & Kecil & 1 \\
\hline
\end{tabular}

TABEL 6.

KEDEKATAN NILAI ATRIBUT RIWAYAT CAESAR (RC)

\begin{tabular}{|c|c|c|}
\hline Nilai 1 & Nilai 2 & Similarity \\
\hline Ya & Ya & 1 \\
\hline Ya & Tidak & 0.5 \\
\hline Tidak & Ya & 0.5 \\
\hline Tidak & Tidak & 1 \\
\hline
\end{tabular}

TABEL 7.

KEDEKATAN NILAI ATRIBUT RIWAYAT PENYAKIT (RP)

\begin{tabular}{|c|c|c|}
\hline Nilai 1 & Nilai 2 & Similarity \\
\hline Ada & Ada & 1 \\
\hline Ada & Tidak & 0.5 \\
\hline Tidak Ada & Ada & 0.5 \\
\hline Tidak Ada & Tidak & 1 \\
\hline
\end{tabular}

\section{IMPLEMENTASI DAN PENGUJIAN}

Dalam Implementasi terdapat 47 kasus yang tersimpan dalam basis kasus.. Penambahan kasus akan terjadi apabila kasus uji memiliki nilai similar di bawah 1. Kasus-kasus yang tersimpan dalam basis kasus dapat dilihat pada Tabel 8.

TABEL 8.

BASIS KASUS

\begin{tabular}{|c|c|c|c|c|c|c|}
\hline Case & $\begin{array}{c}\text { U } \\
\text { (th) }\end{array}$ & $\begin{array}{c}\text { JP } \\
\text { (th) }\end{array}$ & LP & RC & RP & Persalinan \\
\hline 01 & $\begin{array}{c}26 \mathrm{~s} / \mathrm{d} \\
35\end{array}$ & $<2$ & besar & ya & ada & SC \\
\hline 02 & $<=25$ & $<2$ & besar & $\begin{array}{c}\text { belum } \\
\text { pernah }\end{array}$ & $\begin{array}{c}\text { tidak } \\
\text { ada }\end{array}$ & Normal \\
\hline 03 & $<=25$ & $<2$ & besar & $\begin{array}{c}\text { belum } \\
\text { pernah }\end{array}$ & ada & SC \\
\hline 04 & $<=25$ & $<2$ & besar & pernah & $\begin{array}{c}\text { tidak } \\
\text { ada }\end{array}$ & SC \\
\hline 05 & $<=25$ & $<2$ & besar & pernah & ada & SC \\
\hline 06 & $<=2$ & $<2$ & kecil & $\begin{array}{c}\text { belum } \\
\text { pernah }\end{array}$ & $\begin{array}{c}\text { tidak } \\
\text { ada }\end{array}$ & SC \\
\hline 07 & $<=25$ & $<2$ & kecil & $\begin{array}{c}\text { belum } \\
\text { pernah }\end{array}$ & ada & SC \\
\hline$\ldots$ & $\ldots$ & $\ldots$ & $\ldots$ & $\ldots$ & $\ldots$ & $\ldots$ \\
\hline 47 & $<=25$ & $<2$ & kecil & pernah & ada & SC \\
\hline
\end{tabular}

Contoh kasus yang akan diuji.

Misalkan sedang dihadapi kasus sebagai berikut:

Usia Ibu Hamil : 25 s/d 35 tahun

Jarak persalinan : lebih dari 2 tahun

Lebar panggul : Kecil

Riwayat Caesar : belum pernah

Riwayat Penyakit : tidak ada

Bagaimana prediksi proses kelahiran ibu tersebut? 
Langkah pertama yang dilakukan adalah tahap Retrieval yaitu menghitung similaritas kasus uji dengan kasus yang ada di basis kasus. Perhitungan similaritas mengguanakan algoritma nearest neighbor dan didapat hasil simailaritas setiap kasus sebagai berikut.

Similarity with case case $01: 0.2$

Similarity with case case $02: 0.4$

Similarity with case case $03: 0.2$

Similarity with case case $04: 0.2$

Similarity with case case $05: 0.0$

Similarity with case case $06: 0.6$

Similarity with case case $07: 0.4$

\section{Similarity with case case $18: 0.8$}

Similarity with case case $19: 0.2$

$\cdots$

Similarity with case case $46: 0.2$

Similarity with case case $47: 0.2$

Berikutnya adalah tahapan reuse. Dari hasil pengujian diperoleh case yang mempunyai nilai similaraitas yang paling tinggi adalah case 18 dengan nilai similaritas 0.8 . Oleh karena nilai similaritas belum mencapai 1 maka kasus uji bisa dilanjutkan dengan tahapan revise dan tahapan retain yang terlihat pada Gambar 5.

\section{KESIMPULAN DAN SARAN}

Pemanfaatan CBR untuk memprediksi proses persalinan dapat tidak menjamin solusi terbaik atau solusi optimum

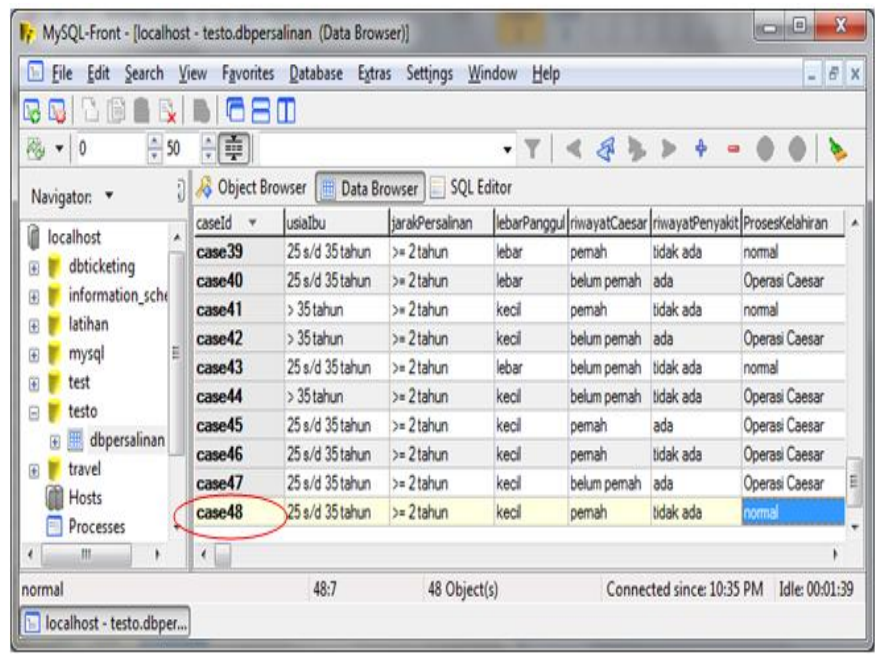

Gambar 5. Penyimpanan kasus baru ke Basis kasus (Retain) karena CBR hanya memberikan solusi berdasarkan kasuskasus yang disimpan.

Pengelohan data yang meliputi kasus-kasus yang menjadi acuan inti dari konsep CBR sangat penting. Kelengkapan dan kekompleksan kasus yang tersimpan dalam basis kasus dapat menjadikan CBR suatu sistem yang dapat menghasilkan solusi optimal dan tepat. Selain itu penentuan atribut yang tepat sangat menentukan solusi yang diharapkan.

Kekurangan CBR adalah membutuhkan metode similaritas yang tepat untuk mencari similar antar kasus. CBR juga membutuhkan tempat penyimpanan yang besar apabila data (kasus) yang disimpan sangat banyak.

\section{REFERENSI}

[1] Abdul Bari Syaifuddin, 'Pelayanan Kesehatan Maternal dan Neonatal", Edisi ke - 1, cetakan ke - 3, JNPKKR - POGI, Yayasan Bina Pustaka Sarwono Prawirohardjo, Jakarta 2002, hal 03-336

[2] Poedji Rochyati, "Skrining Antenatal Pada Ibu Hamil, Pengenalan Faktor Risiko Deteksi Dini Ibu Hamil Risiko Tinggi”, Cetakan-1, Airlangga University Press, Surabaya, 2003.

[3] Watson, I., "Applying Case-Based Reasoning: Techniques for Enterprise Systems",California, Morgan Kaufmann, 1997.

[4] Sankar,Simon, "Foundation Of Soft Case Base Reasoning", WEIley Interscient, 2004.

[5] Petra Perner, Thomas Günther and Horst Perner, "Airborne Fungi Identification by Case-Based Reasoning", Institute of Computer Vision and Applied Computer Sciences Arndtstr.

[6] Kusrini, Emha Taufik Lutfi, "Algoritma Data Mining”, Penerbit Andi Offset, Yogyakarta, 2009.

[7] Juan A. Recio, Antonio Sanchez, Beleb Diaz-Agudo, Pedro GonzalezCalero, "Case Structure jCOLIBRI", Procs. Of the AI-2005 conference. Cambridge. Springer BSC Series. 